\title{
AZ ELVÁRÁSOK ÉS A HANGINGER SZEREPE A BINAURÁLIS ÜTEMEK HALLGATÁSA SORÁN ÁTÉLT SZUBJEKTÍV ÉLMÉNYEKRE*
}

\author{
SZABÓ GERGELY ${ }^{1}$ - DRÓTOS GERGELY² - SZABÓ CSABA ${ }^{3}$ \\ ${ }^{1}$ Debreceni Egyetem, Bölcsészettudományi Kar, Pszichológia Intézet, \\ Személyiség- és Klinikai Pszichológia Tanszék \\ ${ }^{2}$ Szegedi Tudományegyetem, Általános Orvostudományi Kar, Pszichiátriai Klinika \\ ${ }^{3}$ Debreceni Egyetem, Bölcsészettudományi Kar, Pszichológia Intézet, \\ Általános Pszichológiai Tanszék \\ E-mail: gergely.szabo.psy@gmail.com; gergely.drotos@gmail.com; \\ szabo.csaba4032@gmail.com
}

Beérkezett: 2014. május 05. - Elfogadva: 2015. február 26.

\begin{abstract}
Háttér és célok: A binaurális ütemek a két fül közötti frekvenciakülönbség hatására létrejövő pulzáló hangok. A „binaurális ütem” angol megfelelöinek szavaira az internetes keresési találatok az elmúlt három évben megduplázódtak, ami jól példázza az utóbbi időben egyre inkább növekvő érdeklődést. Ezeket a hangokat feltételezett pszichológiai hatásaik miatt keresik, noha a tudományos adatok ellentmondásosak a témában. Tanulmányunkban arra kerestük a választ, hogy a binaurális ütemek hallgatása milyen szubjektív élményeket vált ki a hallgatóból, és ezeket milyen tényezők befolyásolják, tehát hogy mi a szerepe az elvárásoknak, a hang speciális akusztikai tulajdonságainak, illetve a binaurális ütemek frekvenciatartományának.

Módszer: Jelen tanulmányban két vizsgálatot mutatunk be. Az élményeket a (Phenomenology of Consciousness; PCI) élményfeltáró kérdöívvel és a személyekkel készült interjúk tartalomelemzésével mértük. Az elsö vizsgálatban 109, a másodikban 159 egyetemi hallgató vett részt. Az elsö kísérletben az instrukció, a másodikban az ingerek fizikai jellemzőinek hatását vizsgáltuk.
\end{abstract}

* A kutatás a TÁMOP 4.2.4.A/2-11-1-2012-0001 azonosító számú Nemzeti Kiválóság Program Hazai hallgatói, illetve kutatói személyi támogatást biztosító rendszer kidolgozása és működtetése országos program címủ kiemelt projekt keretében zajlott. A projekt az Európai Unió támogatásával, az Európai Szociális Alap társfinanszírozásával valósul meg. 
Eredmények: A binaurális ingerlés hatására a személyek élményei szignifikánsan megváltoztak, és az élményeket befolyásolta az instrukció. A különbözö akusztikai tulajdonságokkal rendelkezö hangok hatásában nem volt különbség.

Következtetések: A binaurális ütemek alkalmasak transzszerü élmények kiváltására. Az átélt élményeket jelentösen befolyásolják az elözetes instrukciók. Az átélt élményeket nem befolyásolja a hangok binaurális tulajdonsága, feltehetóleg az ingerek monotonitása okozza az élményváltozásokat.

Kulcsszavak: binaurális ütemek, fenomenológia, szubjektív élmények, elvárások, monaurális, izokronikus

\section{BEVEZETÉS}

A hallási észlelés során a két fülbe érkező ingerek apró különbségeinek detektálásával válik lehetővé a hangforrás téri lokalizációja, az interaurális/binaurális hangerő, idő és fáziskülönbségek észlelése által. Ha két egymástól kissé eltérő frekvenciájú hangingert egyszerre hallunk, a hullámok interferenciájának hatására egy harmadik összetett hangot észlelünk, aminek az amplitúdója (hangereje) folyamatosan növekszik és csökken a két frekvencia különbségével (ütemfrekvencia). Az ilyen jellegű hangokat, amikor levegőben vagy a stúdióban állítják elő őket, monaurális ütemeknek hívjuk. Ha azonban a két eltérő frekvenciájú hangot sztereó fejhallgatón keresztül halljuk az interferencia nem a levegőben, hanem az agytörzsben (a medial superior olivary nucleusban) jön létre (OSTER, 1973; SCHWARZ és TAYLOR, 2005). A két fülbe érkező, kissé eltérő frekvenciájú hanghullámok tartós fennállása esetén úgynevezett binaurális ütemek jönnek létre, amennyiben az alapfrekvencia $90 \mathrm{~Hz}$ és $1000 \mathrm{~Hz}$ közötti, valamint az interferencia nem haladja meg a $35 \mathrm{~Hz}$-et (Licklider, Webster és Hedlun, 1950; Tobias, 1963). Ennél nagyobb frekvenciakülönbség esetén a hallgató két egymástól elkülönült hangot hall (PERROTT és NELSON, 1969). A hallási észlelés pszichológiai szempontú tanulmányozásában fontos, hogy a binaurális ütemekkel lehetővé válik, olyan lassú hullámhosszú hangok illúziójának létrehozása $(<40 \mathrm{~Hz})$, ami egyébként a hallási küszöb alatt van (OsTER, 1973).

$\mathrm{Az}$ alacsony frekvenciájú szenzoros ingerek elektrofiziológiai és pszichológiai hatásainak vizsgálata a pszichológiában nem új keletű jelenség, habár a kutatások főleg a vizuális csatornán közvetített ingerekre fókuszáltak. A korai elektrofiziológiai vizsgálatok eredményei szerint a kortikális válaszok, lassú hullámú szenzoros ingerekkel befolyásolhatóak (ADRIAN és MATTHEWS, 1934). A további megfigyelések szerint villogó fényekkel lehetséges hasonló frekvenciájú agykérgi aktivitás kiváltása (JASPER, 1936; TOMAN, 1941). Később az eredményeket ritmikus hangokkal is igazolták (Chatrian, Petersen és LAZARTe, 1960; BATra, KuwAdA és MAHER, 1986) és a jelenséget agyi frekvenciakövető válasznak nevezték el (FFR frequency following response) (GARDI, MERzEnich és MCKEAN, 1979; STILlman, CROW és MOUSHEgIAN, 1978). Az elektrofiziológiai vizsgálatokban részt vevők a monoton ingerek hatására pszichológiai változásokról is beszámoltak (WALTER, DOVEY és SHIPTON, 1946), sőt a radarképernyőre fókuszáló katonák transzszerủ élményeit is a radar monoton villogásával magyarázták (KROGER és SCHNEIDER, 
1959). Tehát a kor tudományos eredményei szerint, külső ritmikus szenzoros ingerekkel lehetséges elektrofiziológiai változásokat kiváltani, továbbá a monoton ingerek megváltozott tudatállapotok kialakulását eredményezhetik.

Az elektrofiziológiai vizsgálatok a megváltozott tudatállapotok kutatására is kiterjedtek és az eredmények szerint a különböző helyzetekben specifikus agyi aktivitás regisztrálható, például a relaxáció (PEPER, 1970), a meditáció (HEBERT és LEHMANN, 1977) és a hipnózis (például CRAWFORD és GRUZELIER, 1992) esetében (összefoglalóért lásd VAITL és mtsai, 2005). Logikusnak tủnt tehát feltételezni, hogy a ritmikus audiovizuális ingerekkel célzottan kiváltott agyi elektrofiziológiai frekvenciaváltozások megváltozott tudatállapotok kialakulását eredményezik. Az audiovizuális stimuláció (AVS) lényege, hogy monoton villogó fényekkel és hullámzó, lüktető hangokkal kívánják befolyásolni a kérgi működést, különféle pszichológiai változásokat remélve. Az AVS és a biofeedback módszerek a neuroterápiák közé sorolhatóak, amikor agykérgi változások hatására pszichológiai változásokat kívánnak elérni. Az AVS-t, mint egy hamis biofeedback alkalmazzák a klinikai gyakorlatban is (összefoglalóért lásd: SzABÓ és SzABó, 2014; Collura és SIEver, 2009), továbbá az elképzelésre azóta egy egész fogyasztói, rekreációs iparág épült (például Hemi-Sync, I-Doser, Brain Synchronizer, Neuro-Programmer stb.). Jelen tanulmányban elsősorban az audiovizuális stimuláció során használt audió ingerek egyik fajtájával foglalkozunk részletesen, a binaurális ütemekkel.

A binaurális ütemeket az 1990-es évektől használják (üzleti céllal is) megváltozott tudatállapotok kiváltására (ATWATER, 1997), sőt pár évvel ezelött egy amerikai forgalmazó (I-Doser) egyenesen azt állította, hogy az általa hangdrog néven értékesített binaurális ütemek alkalmasak pszichotrop drogokhoz hasonló élmények indukálására. A binaurális ütemek hatalmas érdeklődést váltottak ki mind a vásárlók, mind a média körében. Bár a vásárlók beszámolói és a sikeres piaci jelenlét a feltételezett pszichológiai hatások mellett szóltak, a tudományos eredmények hiányosak és ellentmondásosak a témában.

A binaurális ütemek hatásmechanizmusa a hangingerek hatására létrejövő tartós kérgi elektrofiziológiai változások kiváltásán alapul, de jelenséget nem tudták egyértelműen alátámasztani. Bár vannak a jelenséget támogató eredmények (például BRADY és STEVENS, 2000), több tanulmány nem talált bizonyítékot a binaurális ütemek hatására létrejövő tartós elektrofiziológiai szinkronizációra (STEVENS és mtsai, 2003, WAHBEh, CALABRESe, Zwickey és ZAJDEL, 2007). Az EEG-vel mérhető adatok ellentmondásossága jellemzi a kognitív és emocionális adatokat vizsgáló tanulmányokat is (összefoglalóért lásd HUANG és CHARYTON, 2008; SZABÓ és SZABÓ, 2014). A binaurális ütemekkel végzett kísérletek során egy alkalommal a kognitív funkciók javulását találták (OWENS, KASIAN és MARSH, 1998), amíg egy másik vizsgálatban nem tudtak hasonló eredményeket mérni (WAHBEH, CALABRESE és ZWICKEY, 2007). Két tanulmányban sikerrel alkalmazták a binaurális ütemeket a szorongás csökkenésre (Le Scouarnec, Poirier, Owens, Gauthier, Taylor és Foresman, 2001; PADMANabHan, Hildret és LaWs, 2005), de van olyan vizsgálat, ahol nem mértek változást (WAHBEH, CALABRESE és ZWICKEY, 2007, WAHBEH, CALABRESE, ZWICKEY és ZAJDEL, 2007), sőt egy alkalommal negatív érzelmi reakciókról is beszámoltak (OwENs és mtsai, 1998). Jellemező továbbá, hogy a hatás- 
mechanizmus létjogosultságát támogató tanulmányok legtöbbször nem szakmailag lektorált folyóiratokban jelennek meg (például Hemi-Sync Journal), a független tudományos folyóiratokban pedig elsősorban a negatív eredmények látnak napvilágot. Tanulmányunkban arra keressük a választ, hogy vajon a binaurális ütemek hallgatása során átélt szubjektív élmények állhatnak-e a hangok piaci sikere, valamint a vásárlók pozitív visszajelzései mögött.

Az egyik legfontosabb tisztázandó kérdés, hogy vajon a binaurális ütemek alkalmasak-e a szubjektív élmények megváltoztatására, és ha igen, milyen feltételek mellett. Mivel a forgalmazók részletes leírásokat mellékelnek a hanganyagokhoz a várható szubjektív élményekről, fontos továbbá tisztázni, hogy vajon az előzetes elvárások mennyiben befolyásolják az átélt élményeket? Elképzelésünk szerint a várható hatások ismerete mintegy előfeszíti az elvárásoknak megfelelő szubjektív élmények átélését. A hatásmechanizmus magyarázatában továbbra is kérdés, hogy mi a szerepe a speciális akusztikai tulajdonságú binaurális ütemek alkalmazásának, ha az agyi frekvenciakövető válasz, akár „klikk” hangokra is létrejöhet. Mivel a binaurális ütemek az agytörzsben jönnek létre és a binaurális észlelés a hangok téri lokalizációjáért felelős, lehetséges-e, hogy a transzindukciós módszerek konfúziós indukciójához hasonlóan a binaurális ütemek a szokatlan térbeli hangészlelés hatására váltanak ki megváltozott élményeket? Korábbi adatok arra utalnak, hogy a megváltozott élmények tartós monoton hangingerlés hatására is létrejöhetnek (SZABÓ, 2006), tehát lehetséges-e, hogy nem a hangingerek akusztikai tulajdonságai, hanem monotonitásuk felelős a kiváltott változásokért?

A következőkben két vizsgálatunkat mutatjuk be, amelyekben a fentebbi kérdésekre kerestük a válaszokat. Az első vizsgálatban arra voltunk kíváncsiak, hogy vajon a binaurális ütemek alkalmasak-e a szubjektív élmények megváltoztatására, ezért két binaurális ütemeket tartalmazó hangfelvétel hatásait hasonlítottunk össze egy sztenderd relaxációs helyzettel. A hangfelvételek hallgatása elött instrukciókat adtunk a résztvevóknek arra vonatkozólag, hogy mit fognak átélni, és az instrukciókat manipuláltuk három csoportban, hogy megtudjuk vajon az előzetes elvárások milyen hatással vannak az átélt élményekre (a vizsgálatot részletesebben lásd: SZABÓ, DRÓtos és SzABÓ, 2014a). A második kísérletben megvizsgáltuk, hogy mennyiben befolyásolja az átélt élményeket a hallgatott hangok akusztikai tulajdonsága, ezért sztereó és monó ingerek hatásait hasonlítottunk össze (a vizsgálatot részletesebben lásd SzABó, Drótos és SzABó, 2014b).

\section{VIZSGÁLAT}

\section{Módszer}

A vizsgálat egy randomizált, önkontrollos kísérlet. A kísérleti alanyok nem ismerték a vizsgálat célját, nem tudták, hogy a különböző csoportok különböző ingereket kapnak. Továbbá az adatok értékelésekor nem lehetett tudni, hogy a személy melyik csoportba tartozik. A vizsgálatban a Debreceni Egyetem hallgatói vettek részt különböző szakokról, önkéntes jelentkezés alapján. A 117 résztvevő közül 
8-an hibásan vagy hiányosan töltötték ki a teszteket, ezért 109 személy adatait elemeztük ( $\mathrm{N}=109$; 19 férfi, 90 nő; életkor 21 év $\mathrm{SD} \pm 4)$.

A vizsgálat a Debreceni Egyetem Pszichológia Intézet laboratóriumában folyt. Minden résztvevő egyénileg vett részt a kísérletben. Minden résztvevő két hangot hallgatott, két külön alkalommal, minimum egy hét eltéréssel, nagyjából azonos időben (hogy elkerüljük a cirkadián ritmusból adódó arousal változásokat).

Minden kísérleti alkalom egy kontrollhelyzet rögzítésével kezdődött, a személyek 5 percig csukott szemmel ültek, majd az élményeiket értékelték a PCI (Phenomenology of Consciousness Inventory, lásd később) kérdőíven. Ezután a résztvevők instrukciókat kaptak arra vonatkozóan, hogy a hallgatók mit szoktak átélni a binaurális ütemek hallgatása során, majd a kísérleti hangok hallgatása következett (csukott szemmel, nyugodt körülmények között), utána pedig ismételten adatrögzítés (kérdőíves és félig strukturált interjú formájában). A következő kísérleti alkalom ugyanígy zajlott, de más kísérleti hangot hallgatott a résztvevő. A hangok hallgatásának sorrendje minden csoportban véletlenszerủ volt.

Az ingereket egy nagy médiafigyelmet kapott, binaurális ütemeket forgalmazó internetes cég hangjai közül választottuk ki (I-Doser). A cég nevére történő internetes keresési találatok 2007 és 2011 nagyon gyakoriak voltak szerte a világon (a Google Trends adatai alapján), és ebben az időszakban vezető médiacsatornák közöltek híreket a céggel kapcsolatban (The Times, Wired, Huffington Post, Psychology Today, News9, NewsOK, index.hu stb.), amelyben a feltételezett pszichológiai hatásokat tárgyalták. Az ingerek kiválasztásánál szempont volt, hogy a gyártó szerint ellentétes hatást váltsanak ki.

Az egyik hang (továbbiakban: negatív hang) hallgatása során a leírások szerint a hallgatók intenzív, akár negatív élményeket is átélhetnek. A forgalmazó a hangot „Isten keze” néven (eredeti nyelven: „Hand of God”) árusítja, és a kísérletben elhangzó instrukciókat a gyártó honlapján található instrukciók alapján alkottuk meg. Tulajdonságaiban ez a delta EEG-tartománynak megfelelő $(0,5-4 \mathrm{~Hz})$ binaurális ütemeket tartalmazta, 100-400 Hz-es hordozó frekvencián.

A másik hang (továbbiakban: pozitív hang) a forgalmazó szerint alkalmas arra, hogy pozitív élményeket és boldogságot váltson ki a hallgatókból, ez az I-Doser honlapján „5HTP” néven található meg, és az általunk használt instrukciós szöveget is a gyártó leírása alapján alkottuk meg. A hang a théta és az alfa EEG tartományba $(4,5-10 \mathrm{~Hz})$ eső binaurális ütemeket tartalmazta $300 \mathrm{~Hz}$-es hordozófrekvencián.

Mindkét hang esetén azonos, közepes hangerőt alkalmaztunk (az előkísérleteken részt vevők visszajelzései alapján. Mindkét hang mögött ún. rózsaszín zaj volt hallható, és mindkét inger egyenként 30 perces volt. A rózsaszín zajra jellemző, hogy energiája 3 decibellel csökken oktávonként, tehát egy olyan széles spektrumú zaj, ami az emberi hallás sajátosságaihoz igazodik. A széles spektrumú zajok maszkolják a külvilág hangingereit, így segíthetik a figyelem szűkítését.

A részvevőket véletlenszerúen 3 csoportba soroltuk. Az egyik csoport (A) a hangokat az eredeti instrukciókkal kapta, ami nagyon hasonlított az interneten található leírásokhoz. Egy másik csoportban (B) felcseréltük a hangokhoz tartozó instrukciókat. A harmadik csoport (C) pedig csak általános instrukciókat kapott 
arra vonatkozóan, hogy most binaurális ütemeket fog hallgatni, ami alatt különféle pszichológiai változásokat élhet át, és figyelje meg, hogy mi történik a hatásukra (kísérleti elrendezést és helyzeteket lásd az 1. táblázatban).

A negatív hang esetében az eredeti, negatív instrukció a következőképpen hangzott: „A binaurális ütemek fejlesztöi szerint ez az egyik leghatásosabb hang. Hallgatása során erösen megélénkülhet a képzelet és az intuició, létrejöhetnek érzékszerven kivuüli észlelések. Megalkotói szerint igen intenzív élményeket válthat ki, amelyek nem minden esetben kellemesek. Néha a hallgatók akár félelmet is átélhetnek." A pozitív hang esetében az eredeti, pozitív instrukció az alábbi volt: „A következökben egy olyan hangot fogsz hallani, amelyet arra terveztek, hogy az agyban serkentse az 5 HTP nevü hormon, ezáltal pedig a szerotonin hormon termelését. Ezek a hormonok a boldogságért felelösek. Alacsony szintjüket összefüggésbe hozzák a depresszióval és a stresszel. Ezt a hangot azért fejlesztették ki, hogy a hormonok termelése által boldog legyél.” Az általános instrukció a következőképpen hangzott: „A következökben úgynevezett binaurális ütemeket fogsz hallani. A binaurális ütemek egy pszichológiai jelenséggel kapcsolatosak. Ez akkor jön létre, ha a két fülbe két, frekvenciájukban nem sokban különbözö hangot adunk, ilyenkor a hallgató egy harmadik hangot fog hallani, amely a két frekvencia különbségén szól. Kutatók feltételezik, hogy az ilyen hangok nyugodt körülmények között, hosszabb idön keresztül hallgatva alkalmasak arra, hogy különféle pszichológiai és hangulatváltozásokat váltsanak ki a hallgatóban."

1. táblázat. A kísérleti elrendezés

\begin{tabular}{|l|c|c|c|}
\hline Helyzet / Csoport & Eredeti instrukciók & Felcserélt instrukciók & Semleges instrukciók \\
\hline 1. Kontroll & A csoport résztvevői & B csoport résztvevői & C csoport résztvevői \\
\hline 2. Pozitív hang & A csoport résztvevői & B csoport résztvevői & C csoport résztvevői \\
\hline 3. Kontroll & A csoport résztvevői & B csoport résztvevői & C csoport résztvevői \\
\hline 4. Negatív hang & A csoport résztvevői & B csoport résztvevői & C csoport résztvevői \\
\hline
\end{tabular}

A sorokban a különböző helyzetek láthatóak, az oszlopokban a különböző csoportokat jelenítettük meg.

Az átélt szubjektív élményeket kérdőívek és félig strukturált beszámolók formájában rögzítettük. A kontroll- és a kísérleti helyzet után is rögzítettük az élményfeltáró kérdőívet, a kísérleti hang hallgatása után pedig egy félig strukturált interjút vettünk fel.

$\mathrm{Az}$ élményfeltáró kérdőívet (Phenomenology of Consciousness Inventory PCI) (Pekala, Wenger és Levine, 1985, Pekala, 1991; Szabó, 1993) a transzállapotok során létrejövő szubjektív élményváltozások mérésére alakították ki. A kérdőív 53 ellentétes mondatpárt tartalmaz, amelyeket hétfokú Likert-típusú skálákon kell megítélni. A kérdőív eredetileg 12 fö- és 14 aldimenzióban mér, de a tapasztalatok szerint egy egyszerűsített 5 faktoros modell a variancia jelentős részét magyarázza (PEKALA, 1991; VARGA, 2004), ezért célszerübbnek láttuk az elemzés során ezt a modellt használni. Az 5 összefoglaló faktor a következő: disszociált kontroll (DK), belső folyamatokra irányuló figyelem (BFF), vizuális képzelet (VK), pozitív érzelmek (PI) és negatív érzelmek (NI). A megváltozott élmények mérése során a legfontosabb adatot a disszociált kontrollfaktor adja, a valóságorientáció és 
az ego végrehajtó funkciók változásáról informál. A belső folyamatokra irányuló figyelem az időérzék, percepció, abszorpció és belső beszéd alskálák változását méri, így a figyelem irányának meghatározásával szintén fontos mérőszám a megváltozott élmények vizsgálatakor.

A félig strukturált interjú során az alábbi kérdéseket használtuk vezérfonalként: 1. szabadon mesélje el, mit élt át, 2. mire gondolt és 3. mit érzett a kísérlet közben a résztvevő, valamint 4. mihez tudná hasonlítani az élményt. Az interjúk szövegeit ezután számítógépen rögzítettük, majd a szöveget az Atlas.ti 6.0 tartalomelemző program segítségével, az Regresszív Képzeleti Szótár (RID) kategóriarendszere alapján elemeztük (SZABó, Drótos és SzABÓ, 2013). Bár a szótár a pszichoanalitikus elméleti keret alapján az elsődleges és másodlagos folyamatokra utaló szövegtartalmakat hivatott mérni, a vizsgálatunk fókusza miatt az érzelmeket vizsgáló főkategóriát vizsgálatuk és elemeztük. A kísérlet során azt vizsgáltuk, hogy a hanganyagok és előzetes instrukciók miként járulnak hozzá a hang hallgatása során átélt érzelmek kialakulásához. Az instrukciók módosításával kívántuk befolyásolni a résztvevők által a hang hatására átélt érzelmeket úgy, hogy azok várhatóan pozitív vagy negatív irányba változzanak. A vizsgálat célkitűzései, valamint a statisztikai modell erősségének szem előtt tartása miatt a Regresszív Képzeleti Szótár 43 elemezhető kategóriája közül csak a pozitív és negatív érzelmekre vonatkozó érzelemkategóriákat vizsgálatuk, ezek: a pozitív érzelmek, szeretet, szomorúság és szorongás.

\section{Eredmények}

Az adatokat SPSS 20.0 statisztikai programmal elemeztük. Az élményfeltáró kérdőív adatait első lépésben többváltozós varianciaanalízissel vizsgáltuk, ahol a független változónk a kísérleti/kontroll helyzet volt, ebben a modellben minden kísérleti és kontrollhelyzet adatai együttesen szerepeltek. Ez után a kísérleti helyzet adatait többváltozós, többszempontos varianciaanalízissel elemeztük, ahol a hang és az instrukció szerepeltek mint független változók. A többszörös összehasonlításokat Bonferroni-eljárással végeztük, a hatások közötti interakciókat pedig $t$-próbával és többszempontos varianciaanalízissel vizsgáltuk. Mivel a tartalomelemzés adatai nem normál eloszlást mutattak, ezért ebben az esetben a Wilcoxon és Mann-Whitney nemparaméteres eljárásokat alkalmaztunk, $p<0,05$ szignifikanciaszintekkel.

\section{A kontroll- és a kísérleti helyzet összehasonlítása}

A kontrollhelyzetet a kísérleti helyzetekkel összehasonlítva szignifikáns különbségeket találtunk $(\mathrm{F}=61,9 ; \mathrm{szf}=5,430 ; p<0,001)$. Az élményfeltáró kérdőív 5 faktorából 4 szignifikánsan nőtt, ezek: a disszociált kontroll $(\mathrm{F}=272,14$; $\mathrm{szf}=1,434$; $p<0,001)$, belső folyamatokra irányuló figyelem $(\mathrm{F}=84,7 ; \mathrm{szf}=1,434 ; p<0,001)$, pozitív $(\mathrm{F}=34,53 ; \mathrm{szf}=1,434 ; p<0,001)$ és negatív érzelmek $(\mathrm{F}=35,07 ; \mathrm{szf}=1,434$; $p<0,001)$. 


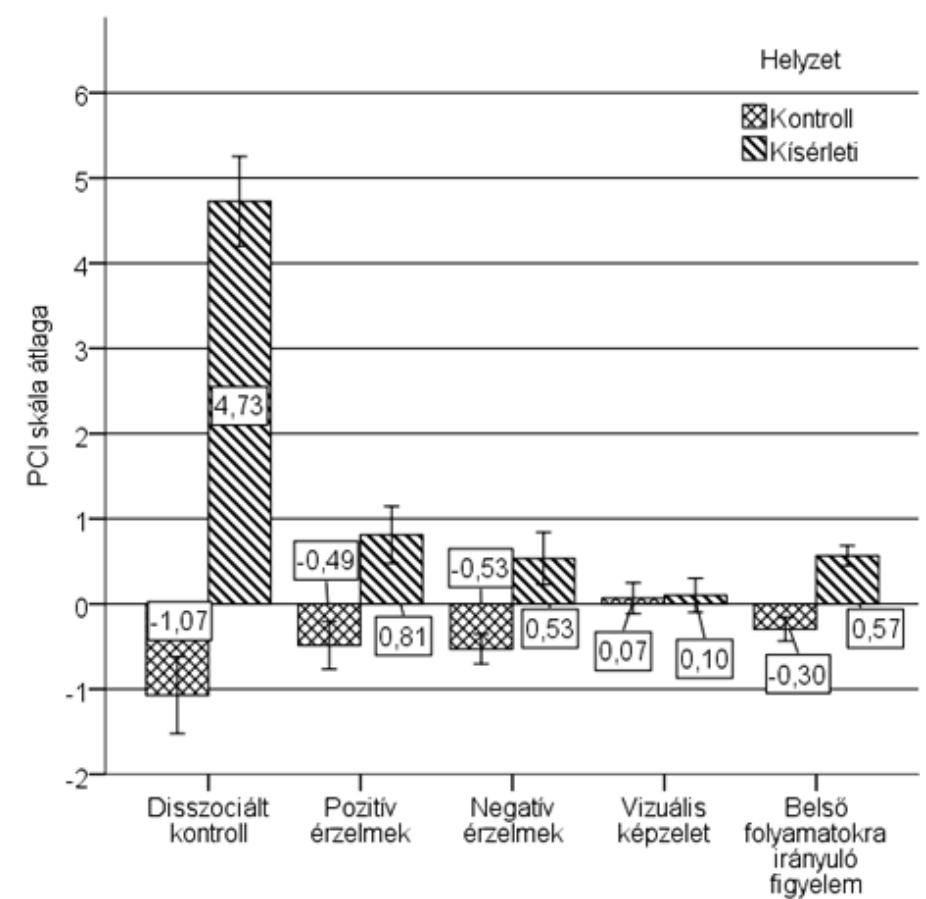

1. ábra. Az élményfeltáró kérdőív (PCI) értékei a kontroll- és kísérleti helyzetekben

\section{Az instrukció hatása}

Az interjúk adatainak tartalomelemzésekor az instrukciók főhatását lehetett kimutatni. A felcserélt instrukciós csoportban több szorongásra utaló tartalmat lehetett regisztrálni a pozitív hang hallgatása után a negatív hanghoz képest $(Z=-2,01$; $p=0,045)$, ugyanez a különbség megfigyelhető volt a semleges instrukciós csoportban is $(\mathrm{Z}=-2,5 ; p=0,012)$. Semleges instrukciós csoportban szignifikáns kevesebb pozitív érzelmekre vonatkozó tartalmat lehetett regisztrálni $\left(\chi^{2}=13,46\right.$; $\mathrm{szf}=2 ; p=0,001)$ mind az eredeti $(\mathrm{Z}=-2,97 ; p=0,003)$, mind a felcserélt instrukciós csoporthoz képest $(\mathrm{Z}=-3,47 ; p=0,001)$. A hangok összehasonlításakor szintén szignifikáns különbségeket találtunk a különböző instrukciók csoportjainál, mind a pozitív érzelmekre $\left(\chi_{2}^{2}=9,79 ; \mathrm{szf}=2 ; p=0,007\right)$, mind a szorongásra utaló tartalmakra $\left(\chi^{2}=7,96 ; \mathrm{szf}=2 ; p=0,02\right)$ vonatkozólag. A pozitív érzelmekre utaló tartalmak a hamis $\left(\chi_{2}=7,96 ; \mathrm{szf}=2 ; p=0,02\right)$ és az eredeti $(\mathrm{Z}=-2 ; p=0,046)$ instrukciós csoportban is többször fordultak elő, mint az általános instrukciók használata esetén. A szorongásra utaló tartalmak pedig szignifikánsan többször fordultak elő az eredeti instrukciós csoportban, mint a felcserélt instrukciós $(\mathrm{Z}=-2,6 ; p=0,009)$, vagy az általános instrukciós $(\mathrm{Z}=-2,07 ; p=0,04)$ csoportokban (lásd 2. ábra). Az elemzett tartalomelemzési kategóriák közül a „szeretet” és a „negatív érzelmek” kategóriák esetén nem volt szignifikáns különbség a különböző instrukciós csoportokban. 


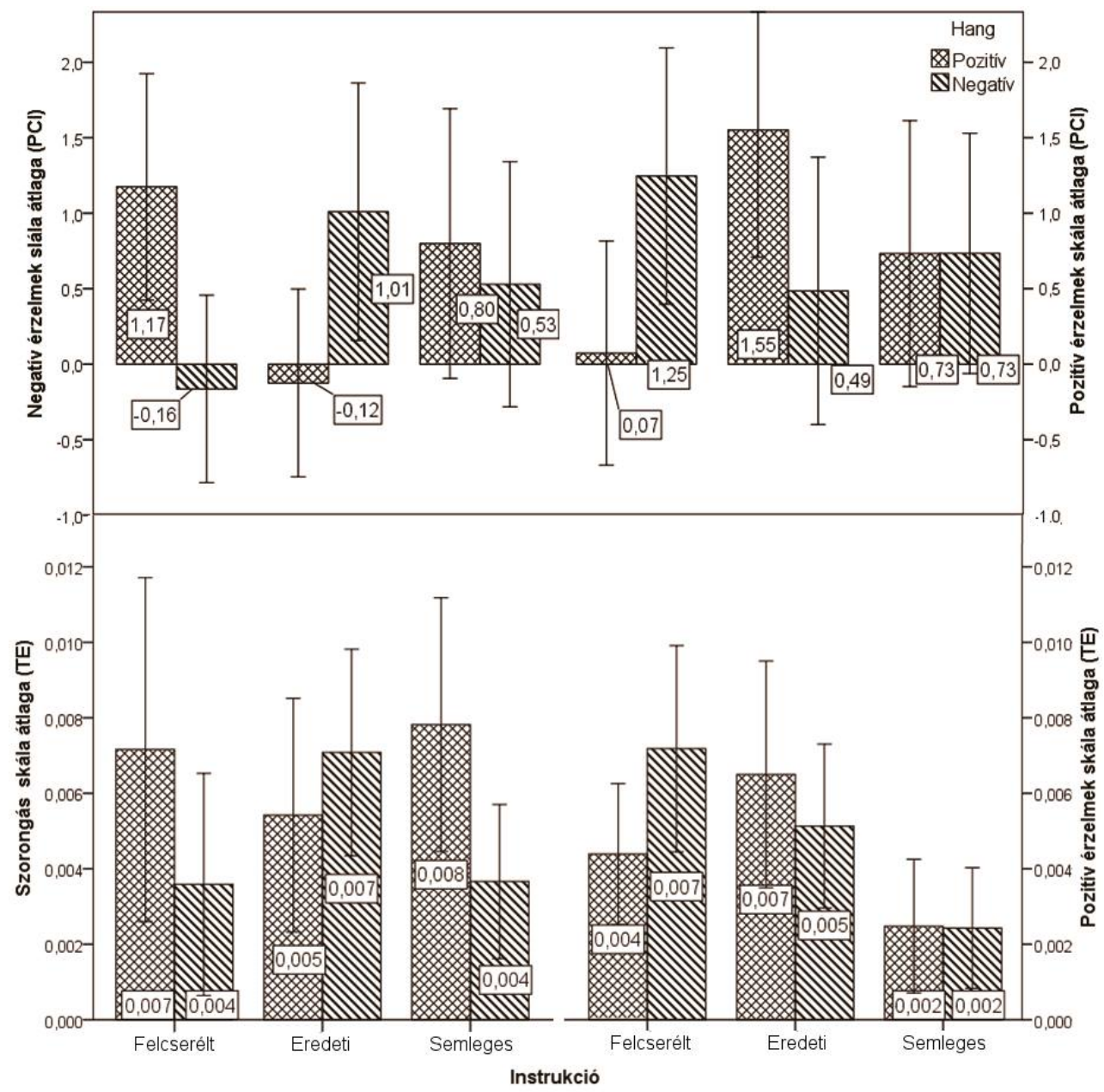

2. ábra. Az élményfeltáró kérdőív (PCI) pozitív és negatív érzelmek skálaértékei csoportok szerinti bontásban (fent). A tartalomelemzés szorongás és pozitív érzelmek skálaértékei (lent). Pozitív érzelmekre utaló adatok a kérdőív és tartalomelemzés eredményein (jobbra). Negatív érzelmekre utaló adatok a kérdőív és tartalomelemzés eredményein (balra).

A kérdőívek elemzésénél nem volt kimutatható az instrukciók főhatása, de interakciót mértünk az instrukciók és a hangok hatása között $(\mathrm{F}=2$; szf $=10,406$; $p=0,03)$, amik pozitív $(\mathrm{F}=3,86 ; \mathrm{szf}=2,206 ; p=0,02)$ és negatív $(\mathrm{F}=6,01, \mathrm{szf}=2,206$; $p=0,003$ ) érzelmek skálaértékei esetén szignifikánsak volt. Hasonlóan a tartalomelemzés eredményeihez, amikor a pozitív hangot pozitív (eredeti) instrukciókkal hallgatták, több pozitív érzelemről számoltak be a kérdőíveken, a felcserélt instrukcióhoz képest $(p=0,03)$. Ugyancsak a pozitív hang és pozitív instrukció helyzetben szignifikánsan alacsonyabb negatív értékeket mértünk az élményfeltáró kérdőíven, akár a felcserélt $(p=0,002)$, akár a semleges $(p=0,03)$ instrukciókhoz 
képest. A negatív hanggal társított fordított (pozitív) instrukció helyzetben, az eredeti és a semleges instrukciós helyzethely képest, magasabb értékeket mutattak a pozitív érzelmek $(t=-2,11 ; \mathrm{szf}=2,70 ; p=0,04)$ és alacsonyabbat a negatív érzelmek skála értékei $(t=2,79 ; \mathrm{szf}=2,70 ; p=0,007)$. Amikor viszont a negatív hangot eredeti (negatív) instrukciókkal hallgatták, a résztvevők több negatív érzelem $(t=-2,18 ; \mathrm{szf}=2,76 ; p=0,03)$ átéléséről számoltak be a pozitív hangos helyzethez képest, amíg semleges instrukció esetén nem volt megfigyelhető ilyen különbség.

\section{Megbeszélés}

Mivel a kérdőív 5 faktorából 4 esetében szignifikáns növekedést találtunk, az adatokból arra lehet következtetni, hogy a binaurális ütemek alkalmasak megváltozott élmények kiváltására. Mivel a kérdőíves mérések során a disszociált kontroll- és a belső folyamatok irányuló figyelem faktorok esetén találtunk növekedést, az eredmények arra utalnak, hogy a résztvevők transzszerü élményeket éltek a hangok hallgatása során, függetlenül attól, hogy milyen típusú hangot milyen instrukcióval hallgattak. Ezen skálák növekedése azt jelzi, hogy a résztvevők átélték például a tér- és időérzék vagy a testhatárok megváltozását, a pszichológiai aktivációs szint változását, valamint hogy a figyelem iránya a külvilágról inkább befelé fordult. Mivel mind a pozitív, mind a negatív érzelmeket mérő skálák értékei szignifikáns mértékben nőttek, eredményeink szerint a binaurális ütemek alkalmasak emocionális változások kiváltására. A pozitív érzelmek főskála mérőszámainak növekedéséből az örömmel, szexuális érzésekkel és szeretettel kapcsolatos érzések növekedésére következtethetünk. Ezzel szemben a negatív érzelmek skála értékeinek növekedése a szomorúság, düh és félelem érzéseinek növekedésére utal.

Eredményeink összhangban vannak a korábbi kutatásokkal, miszerint a binaurális ütemek alkalmasak a hangulat és az érzelmek befolyásolására. Bár a korábbi vizsgálatok elsősorban a szorongás csökkenését mutatták ki (LE SCOUARNEC és mtsai, 2001; Padmanabhan és mtsai, 2005; WaHbeh, CALAbrese, Zwickey és ZAJDEL, 2007), vizsgálatunk tanulsága szerint a megfelelő instrukciók alkalmazásával a negatív érzelmek átélésének valószínűsége is növelhető. Feltételezésünk szerint fontos szerepe van azonban a kísérleti helyzetnek, az elvárásoknak és az instrukcióknak is. Műtét előtti szorongás csökkentésekor a binaurális ütemek mellett a zenét hallgató kontrollcsoportnál is csökkent a szorongás (PADMANABHAN és mtsai, 2005), valamint figyelmi tesztek kitöltése közben hallgatott binaurális ütemek növelhetik is a szorongást (OWENS és mtsai, 1998). Eredményeink alátámasztják az elképzelésünket, miszerint a korábbi vizsgálatokban a binaurális ütemek hallgatása nem közvetlenül járult hozzá a szorongás csökkenéséhez, hanem fontos szerepe volt a kísérleti helyzetnek, az elvárásoknak és instrukcióknak is.

Habár a korábbi vizsgálatok (PADMANABHAN és mtsai, 2005; OWENS és mtsai, 1998) arra utalnak, hogy a binaurális ütemek frekvenciáinak szerepe lehet az érzelmi változások kialakulásában, vizsgálatunk eredményei nem erősítették meg ezt. Eredményeink alapján nem tudtuk kimutatni a hangok főhatását, ami azt su- 
gallja, hogy a binaurális ütemek által kiváltott szubjektív élményeket nem elsősorban a binaurális ütemek frekvenciája határozza meg. Habár az interjúk szövegének tartalomelemzése esetén kimutatható volt az instrukciók fóhatása, a kérdő́ives méréseknél a hangok és az instrukciók interakcióját figyeltük meg. Szemléletes példája ennek a semleges instrukciók esetén vizsgált érzelemkategóriák, ahol jól látható, hogy pozitív érzelmek megélése esetén nincs különbség a hangok hatásai között, ezzel ellentétben megvizsgálva a negatív érzelmeket éppen az a hang váltott ki több negatív megélést, amelynél az ellenkezőjét várhattuk. Az eredmények tehát arra engednek következtetni, hogy a legmarkánsabb élményváltozásokat a hangok és az instrukciók megfelelő kombinációja okozza, noha az instrukció hatása valószínủleg erősebb. Tehát például a résztvevők a legtöbb pozitív élményt várhatóan akkor élik át, ha a pozitívnak gondolt binaurális ütemeket pozitív instrukciókkal kapják.

\section{VIZSGÁLAT}

\section{Módszer}

A kísérlet egy randomizált, vak, személyek közötti faktorokat vizsgáló elrendezés. A vizsgálatban a Debreceni Egyetem hallgatói vettek részt különböző szakokról, önkéntes jelentkezés alapján. Összesen $157(\mathrm{~N}=157)$ ember vett részt a kísérletben (129 nő, 28 férfi, átlagéletkor: 21 év $\mathrm{SD} \pm 2$ ). A vizsgálat előtt a résztvevők nyilatkoztak arról, hogy nincs ismert pszichiátriai vagy neurológiai betegségük, epilepsziás előtörténetük, nem szednek pszichiátriai gyógyszert és hozzájárulnak az adataik kutatási felhasználáshoz.

A vizsgálat a Debreceni Egyetem Pszichológia Intézet kísérleti laboratóriumában folyt. A vizsgálati helyzetben csoportos hanghallgatás történt fejhallgatókkal 3-6 fós csoportokban. A résztvevőket a demográfiai adatok kitöltése után elmondtuk, hogy monoton hangingereket fognak hallgatni 20 percen keresztül, majd megkértük őket, hogy tegyék fel a fejhallgatókat és kövessék az ott elhangzó instrukciókat. A hangok lejátszása előtt informáltuk a résztvevőket, hogy a monoton hangok „különböző hangulati és pszichológiai változásokat válthatnak ki, amenynyiben nyugodt körülmények között hosszabb időn keresztül hallgatják őket”, ezután megkértük őket, hogy csukják be a szemüket és figyeljék, hogy mit történik.

A résztvevőket random módon 3 csoportba soroltuk, annak megfelelően, hogy milyen akusztikai tulajdonságú monoton hangingereket fognak hallgatni. A három különböző hanginger a következő volt: 1 . binaurális ütemek, a 2. monaurális ütemek (a két eltérő frekvencia számítógépen összegezve, monó hangzásban) és az 3. izokronikus ütemek (egyszerủ tiszta hangok és csend váltakozása). A résztvevőket csak arról informáltuk, hogy a monoton hangingerek pszichológiai hatásait vizsgáljuk, és nem tudták, hogy különböző hangingereket hallgatnak. A hangingereket, egy nyílt forráskódú szoftverrel állítottuk elő (Gnaural). A hangok 20 perc hosszúak voltak, $220 \mathrm{~Hz}$-es alapfrekvencián 1,5 Hz-es binaurális ütemekkel. 
A monaurális és izokronikus hangok mindenben megegyeztek a binaurális hanggal, csak akusztikai tulajdonságukban tértek el. Az elektrofiziológiai delta $(<4 \mathrm{~Hz})$ frekvenciatartomány hangjait alkalmaztuk, mert szakirodalom alapján ezek a hangok alkalmasak lehetnek a relaxáció elősegítésére és a szorongás csökkentésére (CANTOR és EvANS, 2013), így a szubjektív élmények megváltoztatására.

A kísérleti hangok hallgatása után megkértük a résztvevőket, nyílt végủ kérdések segítségével (lásd az 1. vizsgálatot) írják le, hogy mit éltek át az elmúlt percekben. A beszámolók adatait később a Regresszív Képzeleti Szótár (lásd korábban) kategóriáit alkalmazva számítógépes tartalomelemzéssel számszerűsítettük. Ezután az élményfeltáró kérdőívet (PCI - lásd korábban) töltötték ki a résztvevők. Minden adat felvétele számítógépen, online felületen történt.

\section{Eredmények}

Az adatokat SPSS 20.0 statisztikai programmal elemeztük. A három hang hatását az élményfeltáró kérdőív (PCI) összefoglaló skáláira és a tartalomelemzés fő kategóriáinak elemzésekor többváltozós, több szempontú varianciaanalízissel elemeztük, és az eredmények szerint a különböző hangingerek hatása között nem volt különbség a különböző hangokat hallgató csoportok között. A kérdőíves és a tartalomelemzéses módszerek kölcsönösen megerősítették az eredményeket (az átlagértékeket lásd a 2. táblázatban).

2. táblázat. a PCI és tartalomelemzés (RID) skáláinak értékei a különböző hangokat hallgató csoportok szerint

\begin{tabular}{|c|c|c|c|c|c|c|}
\hline \multirow[b]{3}{*}{ PCI } & \multicolumn{6}{|c|}{$\begin{array}{llll}\mathrm{H} & \mathrm{A} & \mathrm{N} & \mathrm{G} \\
\end{array}$} \\
\hline & \multicolumn{2}{|c|}{ Binaurális } & \multicolumn{2}{|c|}{ Monaurális } & \multicolumn{2}{|c|}{ Izokronikus } \\
\hline & Átlag & ( \pm Szórás) & Átlag & ( \pm Szórás) & Átlag & ( \pm Szórás) \\
\hline Disszociált kontroll & 0,02 & $( \pm 3,51)$ & $-0,34$ & $( \pm 3,55)$ & $-1,64$ & $( \pm 3,51)$ \\
\hline Pozitív érzelmek & $-0,03$ & $( \pm 2,08)$ & $-0,11$ & $( \pm 1,71)$ & $-0,68$ & $( \pm 1,8)$ \\
\hline Negatív érzelmek & $-0,17$ & $( \pm 1,86)$ & $-0,21$ & $( \pm 1,82)$ & $-0,09$ & $( \pm 1,67)$ \\
\hline Vizuális képzelet & $-0,13$ & $( \pm 1,37)$ & $-0,34$ & $( \pm 1,32)$ & $-0,15$ & $( \pm 1,3)$ \\
\hline $\begin{array}{l}\text { Belső folyamatokra } \\
\text { irányuló figyelem }\end{array}$ & 0,10 & $( \pm 1,04)$ & 0 & $( \pm 0,78)$ & $-0,09$ & $( \pm 0,9)$ \\
\hline \multicolumn{7}{|l|}{ Tartalomelemzés } \\
\hline Elsődleges folyamatok & 0,159 & $( \pm 0,053)$ & 0,166 & $( \pm 0,041)$ & 0,144 & $( \pm 0,037)$ \\
\hline Másodlagos folyamatok & 0,130 & $( \pm 0,034)$ & 0,127 & $( \pm 0,028)$ & 0,138 & $( \pm 0,032)$ \\
\hline Érzelmek & 0,033 & $( \pm 0,017)$ & 0,034 & $( \pm 0,024)$ & 0,031 & $( \pm 0,015)$ \\
\hline
\end{tabular}




\section{Megbeszélés}

A második vizsgálat eredményei szerint a binaurális ütemek hallgatása során átélt szubjektív élmények nem különböznek jelentősen más akusztikai tulajdonságokkal rendelkező hangingerektől. Sem a kérdőív, sem a tartalomelemzés adatait elemezve nem találtunk különbséget az binaurális, monaurális és izokronikus hangokat hallgató csoportok között, tehát az eredményekből arra következtethetünk, hogy a hangingerek monotonitása felelős a megváltozott élmények kialakulásáért és nincs szerepe az agytörzsben létrejövő hallási észlelési mellékterméknek (binaurális észlelés) a szubjektív élményekre.

Korábbi szakirodalmak alapján feltételezhető, hogy a megváltozott élmények létrejöttében nem csupán hangingerek monotonitása játszik fontos szerepet. A rituális dobolásos szertartásokról készült tanulmányok szerint (NEHER, 1962) a monoton hangingerek hatására megváltozó élmények kialakulásában a mély és hangos basszusfrekvenciák, a monoton ritmikai mintázatok, valamint az állandó tempó (percenkénti ütésszám) játszik szerepet. A binaurális ütemeket tartalmazó felvételek estében pedig az előbbi feltételek mind teljesülnek.

Továbbá a monoton dobolás hatásait vizsgáló kísérletek (SzABÓ, 2006, 2007) tanulsága szerint a megváltozott élmények létrejöttét a monotonitás mellett a hangerő is befolyásolja. Magasabb hangerő mellett markánsabban változtak meg a hallgatók élményei. Meglepő módon a dobolás tempójának változtatása (70, 140, 210 percenkénti ütésszám) nem okozott szignifikáns különbségeket az élményekben (SzABó, 2007), ami szintén megerősíti eredményeinket, miszerint a monoton hangingerek tempója nem befolyásolja az élményeket.

\section{KÖVETKEZTETÉSEK}

Az első vizsgálat eredményei szerint a binaurális ütemek alkalmasak a megváltozott élmények kiváltására, továbbá az eredmények azt mutatják, hogy a hallgatók jelentős része transzszerű élményeket él át a hangok hallgatása során. Vizsgálatunkban választ találtunk rá, hogy a releváns, megbízható tudományos vizsgálatok eredményeinek ellentmondásossága ellenére, miért népszerűek továbbra is a binaurális ütemek a rekreációs célú felhasználók körében.

Adatainkból kiderül továbbá, hogy a binaurális ütemek hallgatása során átélt élményeket elsősorban az előzetesen adott instrukciók befolyásolják jelentős mértékben. Eredményeink szerint az előzetes instrukciók elvárásokat alakítanak ki a hallgatókban és mintegy előfeszítik a későbbi élményeket, tehát például ha valakinek azt mondjuk, hogy kellemes élményeket fog átélni a hang hatására, valószínűbb hogy később ennek megfelelő élményekről fog beszámolni. Ezek az eredmények tovább erősítik a megváltozott tudatállapotok kutatásában közkeletű elképzelést, amit „set és setting”-nek hívnak és az előzetes elvárások (set) szerepét hangsúlyozza a megváltozott élmények kialakulása során (LEARY és DASS, 1995). A binaurális ütemeket forgalmazók és használók szerint a kívánt hatások elérése érdekében fontos, hogy a hangokat nyugodt körülmények között, lehetőleg fél- 
homályban, kényelmes pozícióban hallgassák, ezzel megteremtve az ideális feltételeket (setting) a figyelem befelé fordulásához és a megváltozott élmények kialakulásához.

Mindkét kísérletben megvizsgáltuk, hogy a különböző monoton hangingerek milyen különbségekkel bírnak a szubjektív élmények változásának szempontjából. Az első vizsgálatban delta és théta elektrofiziológiai frekvenciatartományú binaurális hangingereket hasonlítottunk össze és nem volt kimutatható a hangok sajátosságainak főhatása. A második vizsgálat során a hangok akusztikai tulajdonságait manipuláltuk, azaz azonos frekvenciájú binaurális, monaurális és izokronikus ütemeket hallgató csoportokat hasonlítottunk össze. Az eredmények szerint ebben az esetben sem volt lényeges eltérés a különböző akusztikai tulajdonságú hangok hatásai között, sem az élményfeltáró kérdőíven, sem a beszámolókon végzett tartalomelemzés adataiban. Adataink tehát tovább erősítik a korábbi eredményeket, miszerint a monoton hangingerek alkalmasak a transzszerű élmények kiváltására (SZABÓ, 2006, 2007).

Az egyik legfontosabb megállapítása a fentebb tárgyalt vizsgálatoknak, hogy az eredmények szerint a binaurális ütemek más monoton hangingerekhez hasonlóan alkalmasak lehetnek a pszichológiai élmények megváltoztatására. Eredményeink arra engednek következtetni, hogy a binaurális ütemek hatásmechanizmusában szerepet játszanak az előzetes elvárások, egy relaxációhoz hasonló helyzet kialakítása, valamint a figyelem beszűkítése, ami általánosságban elmondható a legtöbb pszichológiai úton létrehozott megváltozott tudatállapotról (VAITL és mtsai, 2005), azonban a binaurális ütemek hallgatása esetén a monoton hangingerre irányított figyelem fokozhatja az előbbi tényezők hatását.

\section{IRODALOM}

Adrian, E. D., \& Matthews, B. H. C. (1934). The Berger rhythm: potential changes from the occipital lobes in man. Brain, 57(4), 355-385.

Atwater, F. H. (1997). Accessing anomalous states of consciousness with a binaural beat technology. Journal of Scientific Exploration, 11(3), 263-274.

Batra, R., KuWAdA, S., \& MAHER, V. L. (1986). The frequency-following response to continuous tones in humans. Hearing Research, 21(2), 167-177.

Brady, B., \& STEvens, L. (2000). Binaural-beat induced theta EEG activity and hypnotic susceptibility. American Journal of Clinical Hypnosis, 43(1), 53-69.

Cantor, D. S., \& Evans, J. R. (Eds.) (2013). Clinical neurotherapy: application of techniques for treatment. San Diego: Academic Press.

Chatrian, G. E., Petersen, M. C., \& Lazarte, J. A. (1960). Responses to clicks from the human brain: some depth electrographic observations. Electroencephalography and Clinical Neurophysiology, 12(2), 479-489.

Collura, T. F., \& Siever, D. (2009). Chapter 8 - Audio-visual entrainment in relation to mental health and EEG. In T. H. Budzynski, H. K. Budzynski, J. R. Evans, \& A. Abarbanel (Eds.), Introduction to Quantitative EEG and Neurofeedback (Second Edition) (195-224). San Diego: Academic Press. 
Crawford, H. J., \& Gruzelier, J. H. (1992). A midstream view of the neuropsychophysiology of hypnosis: Recent research and future directions. In E. FrOMM, \& M. R. NASH (Eds.), Contemporary hypnosis research (227-266). New York: Guilford Press.

Gardi, J., Merzenich, M., \& MCKean, C. (1979). Origins of the scalp-recorded frequencyfollowing response in the cat. International Journal of Audiology, 18(5), 353-380.

Hebert, R., \& LEHMANN, D. (1977). Theta bursts: an EEG pattern in normal subjects practising the transcendental meditation technique. Electroencephalography and Clinical Neurophysiology, 42(3), 397-405.

HuAnG, T. L., \& Charyton, C. (2008). A comprehensive review of the psychological effects of brainwave entrainment. Alternative Therapies in Health and Medicine, 14(5), 38-50.

JASPER, H. H. (1936). Cortical excitatory state and synchronism in the control of bioelectric autonomous rhythms. Cold Spring Harbor Symposia on Quantitative Biology, 4, 320-338.

Kroger, W. S., \& SChneider, S. A. (1959). An electronic aid for hypnotic induction: A preliminary report. International Journal of Clinical and Experimental Hypnosis, 7(2), 93-98.

Le Scouarnec, R.-P., Poirier, R. M., Owens, J. E., Gauthier, J., Taylor, A. G., \& ForesMAN, P. A. (2001). Use of binaural beat tapes for treatment of anxiety: a pilot study of tape preference and outcomes. Alternative Therapies in Health and Medicine, 7(1), 58-63.

LEARY, T., \& DASS, R. (1995). The psychedelic experience: A manual based on the Tibetan book of the dead. New York: Citadel Press.

Licklider, J. C. R., Webster, J. C., \& Hedlun, J. M. (1950). On the frequency limits of binaural beats. The Journal of the Acoustical Society of America, 22(4), 468-473.

NeHER, A. (1962). A physiological explanation of unusual behavior in ceremonies involving drums. Human Biology, 34, 151-160.

Oster, G. (1973). Auditory beats in the brain. Scientific American, 229(4), 94-102.

OWEns, J. D., KASIAN, J. E., \& MARSH, G. R. (1998). Binaural auditory beats affect vigilance performance and mood. Physiology \& Behavior, 63(2), 249-252.

Padmanabhan, R., Hildreth, A. J., \& Laws, D. (2005). A prospective, randomised, controlled study examining binaural beat audio and pre-operative anxiety in patients undergoing general anaesthesia for day case surgery. Anaesthesia, 60(9), 874-877.

Pekala, R. J., Wenger, C. F., \& Levine, R. L. (1985). Individual differences in phenomenological experience: states of consciousness as a function of absorption. Journal of Personality and Social Psychology, 48(1), 125-132.

PeKala, R. J. (1991). Quantifying Consciousness. New York: Springer.

PEPER, E. (1970). Feedback regulation of the alpha electroencephalogram activity through control of the internal and external parameters. Kybernetik, 7(3), 107-112.

Perrott, D. R., \& Nelson, M. A. (1969). Limits for the detection of binaural beats. The Journal of the Acoustical Society of America, 46, 1477.

SChWARZ, D. W. F., \& TAYLOR, P. (2005). Human auditory steady state responses to binaural and monaural beats. Clinical Neurophysiology, 116(3), 658-668.

Stevens, L., Haga, Z., Queen, B., Brady, B., Adams, D., Gilbert, J., et al. (2003). Binaural beat induced theta EEG activity and hypnotic susceptibility: contradictory results and technical considerations. American Journal of Clinical Hypnosis, 45(4), 295-309.

Stillman, R. D., Crow, G., \& Moushegian, G. (1978). Components of the frequencyfollowing potential in man. Electroencephalography and Clinical Neurophysiology, 44(4), 438-446. 
SzABÓ, Cs. (1993). The phenomenology of the experiences and the depth of hypnosis: Comparison of direct and indirect induction techniques. International Journal of Clinical and Experimental Hypnosis, 41(3), 225-233.

SzABó, Cs. (2006). The effect of monotonous drumming on subjective experiences. In D. Aldridge, \& J. FAChner (Eds.), Music and Altered States. Consciousness, Transcendence, Therapy and Addictions (51-59). London: Jessica Kingsley Publishers.

SzABó Cs. (2007). Utazások az alsó világba. Debrecen: Kossuth Egyetemi Kiadó.

Szabó, G., Drótos, G., \& SzAbó, Cs. (2013). The Hungarian Adaptation of the Regressive Imagery Dictionary. Pszichoterápia, 22(3), 176-185.

SzABÓ G., Drótos G. és SzABÓ Cs. (2014a). A binaurális ütemek szubjektív élményekre gyakorolt hatásainak összehasonlítása más akusztikai tulajdonságú hangokkal. In MüNNICH Á. (szerk.), Pszichológiai kutatások (195-203). Debrecen: Debreceni Egyetemi Kiadó.

Szabó, G., Drótos, G., \& Szabó, Cs. (2014b). Subjective Experiences During Binaural Beat Listening: The Effects of the Expectations and the Stimuli. Journal of Alternative and Complementary Medicine. Lektorálásra beküldött kézirat.

SzABÓ G. és SZABÓ Cs. (2014). Az audiovizuális stimuláció gyakorlati felhasználási területei. In Münnich Á. (szerk.), Pszichológiai Kutatások (179-193). Debrecen: Debreceni Egyetemi Kiadó.

Tobias, J. V. (1963). Application of a "Relative" Procedure to a Problem in Binaural-Beat Perception. The Journal of the Acoustical Society of America, 35(9), 1442-1447.

Toman, J. (1941). Flicker potentials and the alpha rhythm in man. Journal of Neurophysiology, 4(1), 51-61.

Vaitl, D., Birbaumer, N., Gruzelier, J., Jamieson, G. A., Kotchoubey, B., Kübler, A., et al. (2005). Psychobiology of altered states of consciousness. Psychology of Consciousness: Theory, Research, and Practice, 131(1), 2-47.

VARGA K. (2004). A hipnotikus kapcsolat élményvilágának interakciós szemléletű elemzése. Habilitációs értekezés. Kézirat. ELTE, Budapest.

Wahbeh, H., Calabrese, C., \& Zwickey, H. (2007). Binaural beat technology in humans: a pilot study to assess psychologic and physiologic effects. The Journal of Alternative and Complementary Medicine, 13(1), 25-32.

Wahbeh, H., Calabrese, C., Zwickey, H., \& Zajdel, D. (2007). Binaural beat technology in humans: a pilot study to assess neuropsychologic, physiologic, and electroencephalographic effects. The Journal of Alternative and Complementary Medicine, 13(2), 199-206.

Walter, W. G., Dovey, V. J., \& Shipton, H. (1946). Analysis of the electrical response of the human cortex to photic stimulation. Nature, 158(4016), 540-541. 


\title{
THE EFFECTS OF THE EXPECTATION AND SOUND STIMULI ON THE SUBJECTIVE EXPERIENCES OF BINAURAL BEAT LISTENING
}

\author{
SZABÓ, GERGELY - DRÓTOS, GERGELY - SZABÓ, CSABA
}

Background and objectives: Binaural beats are pulsating tones created by the frequency difference between the two ears. The internet search results of the term "binaural beats" doubled in the last three years, which demonstrates the growing interest lately. The attention is due to their assumed psychological effects, although the scientific data are controversial in the topic. In our study, we examined the influencing factors of the subjective experiences during listening to binaural beats, such as the role of the expectations, the special acoustic characteristics of the sound and the binaural beat frequency range.

Method: In this study, we present two experiments. The experiences were measured with PCI questionnaire - Phenomenology of Consciousness - and the content analysis of the interviews conducted with the subjects. 109 university students took part in the first and 159 in the second experiment. We examined the effects of the instruction in the first experiment and the physical characteristics of the stimuli in the second.

Results: The experiences have changed significantly as a result of binaural stimulation and the experiences were influenced by the instruction. There was no significant difference between the effects of the sounds with different acoustical characteristics.

Conclusions: Binaural beats are capable of inducing trance-like experiences. The subjective experiences are mainly influenced by preliminary instructions. The characteristics of the binaural stimuli did not have an effect on subjective experiences; presumably it is the monotony of the stimuli that plays a key role in the altered experiences.

Key words: binaural beats, phenomenology, subjective experiences, expectations, monaural, isochronic 